DOERMOTC - 020142

\title{
ENHANCED STUFFING BOX RUBBERS TEST REPORT
}

\author{
November 2001 - June 2002 \\ Date Published: July 2002 \\ Prepared for the United States Department of Energy/Rocky Mountain Oilfield Testing \\ Center
}

\section{J. Rochelle}

Work Performed Under Rocky Mountain Oilfield Testing Center CRADA No. 2002-01 Date 


\section{DISCLAIMER}

This report was prepared as an account of work sponsored by an agency of the United States Government. Neither the United States Government nor any agency thereof, nor any of their employees, make any warranty, expresses or implied, nor assumes any legal liability or responsibility for the accuracy, completeness, or usefulness of any information, apparatus, product, or process disclosed, or represents that its use would not infringe privately owned rights. Reference herein to any specific commercial product, process, or service by trade name, trademark, manufacturer, or otherwise does not necessarily constitute or imply its endorsement, recommendation, or favoring by the United States Government or any agency thereof. The views and opinions of authors expressed herein do not necessarily state or reflect those of the United States Government or any agency thereof. 


\begin{abstract}
The Rocky Mountain Oilfield Testing Center (RMOTC) and Scott's Oil Field Service tested an enhanced stuffing box rubber at the Naval Petroleum Reserve \#3. The enhanced stuffing box rubbers have saved money from not having to replace packing as often and not spilling valuable oil on the ground. A reduction in environmental hazards and the cost of cleaning up spilled oil have also been a benefit.
\end{abstract}


The Rocky Mountain Oilfield Testing Ce nter (RMOTC) and Scott 's Oil Field Service tested an enhanced stuffing box rubber at the Naval Petroleum Reserve \#3. The product was tested on three wells with a history of stuffing box leaks.

A large variety of field conditions are encountered in the production of oil wells. A stuffing box is a seal assembly for polish rod pumping oil wells commonly used in oil and gas wells to contain well bore fluids from spilling onto the surface. Many oil-bearing formations contain large quantities of water, which are pumped from the well bore along with oil and gas. This produces a problem in which the lubricating qualities of the oil well fluid are greatly reduced. As a result, the outer periphery of the polish rod may be worn rapidly, as well as the packing glands. Many wells produce from other types of subsurface formations may have a tendency to "pump off" or become very dry. Under these conditions serious friction problems develop between the polish rod and the packing glands. The gland members may be burned or seriously damaged. Other wells are very old and have been producing for several years. The polish rod on some of these wells may be worn and pitted thereby creating a difficult sealing problem around the outer periphery.

When sealing problems develop, oil and water can be released onto the ground surrounding the oil well. In turn, this can create environmental hazards along with a loss of oil production for the producers.

Three test wells were selected from rod pumped stripper wells. These wells had a history of packing element wear. New packing was replaced every three weeks to a month on these wells.

During a seven-month testing period, the wells were monitored for fluid leakage at the top of the stuffing box, over heating of polish rod, and wear and replacement of packing rubbers.

On two wells, the enhanced stuffing box rubbers worked very well. There were no leaks, downtime, or lost production over the seven-month period.

On the third well, the enhanced stuffing box rubber failed after one month. An analysis of the well fluids was made to improve performance. The pumping unit was aligned correctly over the well. A new packing rubber with a graphite impregnated rope was installed. The new enhanced stuffing box rubber is now working very well on the third well.

The enhanced stuffing box rubbers are capable of providing a better longer lasting seal than conventional stuffing box rubbers. It allows the polish rod to operate cooler and reduces the amount of attention required to prevent leakage.

The enhanced stuffing box rubbers have saved money from not having to replace packing as often and not spilling valuable oil on the ground. A reduction in environmental hazards and the cost of cleaning up spilled oil have also been a benefit. 
The enhanced stuffing box rubbers developed by Scott Lappin d.b.a. LappinTech at this time have not been patented so we cannot go into detail on how they are made.

Enhanced stuffing box rubbers replace standard packing in most models of stuffing boxes including but not limited to cone style Huber and Skinner style jack boxes. This replacement does not require any additional fittings or alteration of stuffing boxes.

The cost of the enhanced stuffing box rubbers is projected to be less than twice the cost of conventional packing rubbers at around $\$ 30.00$ per well site. 